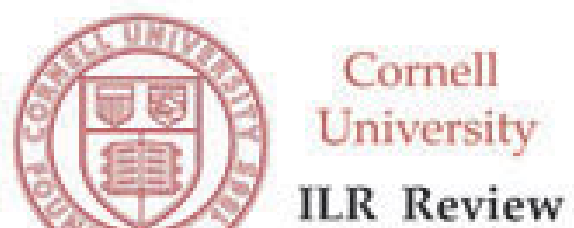

The Decision to Work by Married Immigrant Women

Author(s): Harriet Orcutt Duleep and Seth Sanders

Source: Industrial and Labor Relations Review, Vol. 46, No. 4 (Jul., 1993), pp. 677-690

Published by: Cornell University, School of Industrial \& Labor Relations

Stable URL: http://www.jstor.org/stable/2524311

Accessed: 09/07/2009 17:42

Your use of the JSTOR archive indicates your acceptance of JSTOR's Terms and Conditions of Use, available at http://www.jstor.org/page/info/about/policies/terms.jsp. JSTOR's Terms and Conditions of Use provides, in part, that unless you have obtained prior permission, you may not download an entire issue of a journal or multiple copies of articles, and you may use content in the JSTOR archive only for your personal, non-commercial use.

Please contact the publisher regarding any further use of this work. Publisher contact information may be obtained at http://www.jstor.org/action/showPublisher?publisherCode=cschool.

Each copy of any part of a JSTOR transmission must contain the same copyright notice that appears on the screen or printed page of such transmission.

JSTOR is a not-for-profit organization founded in 1995 to build trusted digital archives for scholarship. We work with the scholarly community to preserve their work and the materials they rely upon, and to build a common research platform that promotes the discovery and use of these resources. For more information about JSTOR, please contact support@jstor.org.

Cornell University, School of Industrial \& Labor Relations is collaborating with JSTOR to digitize, preserve and extend access to Industrial and Labor Relations Review. 


\title{
THE DECISION TO WORK BY MARRIED IMMIGRANT WOMEN
}

\author{
HARRIET ORCUTT DULEEP and SETH SANDERS*
}

\begin{abstract}
Using 1980 Census data, the authors analyze the labor force participation of married immigrant Asian women by country of origin, compared with that of married immigrant women from Europe and Canada. The results suggest the existence of a family investment strategy: evidence from both across groups and within groups indicates that a woman's decision to work is affected by whether she has a husband who invests in skills specific to the U.S. labor market, and also by the extent of that investment. Such a family response may help offset the low earnings of immigrant men who initially lack skills for which there is a demand in the American labor market.
\end{abstract}

A lthough numerous studies have analyzed the assimilation of immigrant men, the role of women has received less attention. Yet, the way the family as a whole copes with immigration is crucial, particularly given the low earnings of men in several immigrant groups during their initial years in the United States.

More generally, examining assimilation from a family perspective may shed light on the questions of how many immigrants we

*Harriet Orcutt Duleep is a Senior Research Associate on leave from the Urban Institute as an American Statistical Association/NSF/Census Bureau research fellow and as a visiting scholar at the Division of Economic Research, Social Security Administration. Seth Sanders is Assistant Professor of Economics at the Heinz School of Public Policy and Management at Carnegie-Mellon University. This paper has benefited from useful comments by Arnold Katz, Sanders Korenman, Evelyn Lehrer, Mark Regets, Finis Welch, and participants of the Georgetown University Labor Economics Seminar, the Donner Foundation-Minnesota Industrial Relations Center Conference on the Economic Well-Being of Women and Children, and CSWEP sessions of the American Economic Association and Eastern Economic Association annual meetings. should admit and whether it is desirable to admit immigrants on the basis of kinship as opposed to occupational skills (Goldfarb 1982; Duleep and Regets 1992). Studies of male earnings suggest that kinship-based admissions have contributed to a decline in immigrant productivity (Borjas 1987). From a social cost and benefit perspective, however, an emphasis on male earnings may be inappropriate given the importance of female earnings in explaining family income differences among ethnic groups (Reimers 1984). Asian immigrants are relevant to this debate because they contribute more to U.S. legal immigration than any other group and, with the exception of the Japanese, are admitted almost exclusively on the basis of kinship; entrants to the country from historically traditional sources of immigration, Europe and Canada, are more likely to enter via occupational skills.

This paper takes as a point of departure the fact that married women in all Asian immigrant groups except the Japanese are more likely to work than are non-Hispanic white immigrant women (women originating from Europe and Canada). Several 
considerations-for example, the relative recency of Asian immigrant women's entry into the country, their generally low divorce and separation rates, and the high prevalence among them of small children at home-might lead one to expect the opposite. We try to account for this seeming paradox. Doing so may help elucidate determinants of labor force participation among immigrant women in general.

Our analysis is based on the 5\% "A" Public Use Sample of the 1980 Census of Population. Our focus is limited to immigrant women, ages 25 to 65 , married to men of the same race and nativity.

\section{The Relative Labor Force Participation of Married Asian Immigrant Women}

The figures in Table 1 document the phenomenon remarked above: married immigrant women from all Asian countries, with the notable exception of Japan, are more likely to work than are non-Hispanic white immigrant women.

One reason this pattern is surprising is that Asians are more likely to be recent immigrants than the benchmark group of nonHispanic whites (Table 1). Several studies have found that the propensity of immigrant women to work increases with years since migration, perhaps reflecting a "cultural assimilation" or the learning of skills relevant to the U.S. labor market. It seems reasonable to expect a period of assimilation to be particularly important for women coming from cultures very different from that in the United States, and from countries that are, with the exception of Japan, less economically developed. ${ }^{1}$

\footnotetext{
${ }^{1}$ With the exception of Japan, Asian countries have substantially lower per capita GNP than the United States (U.S. Bureau of the Census 1992). Borjas found country-of-origin per capita GNP to be strongly positively associated with male immigrant earnings: "This effect is likely... caused by the fact that the higher the GNP...the greater the resemblance between that country's economic structure and that of the United States" (Borjas 1987:547). To the extent that female labor force participation is a function of the market wage, one would expect this factor to be associated with lower labor force participation among Asian immigrant women other than the Japanese.
}

Second, although a majority of Filipino and Asian Indian women are proficient in English, only a small percentage of Chinese and Korean immigrant women report being proficient in English. A limited command of English should hinder labor force participation.

Third, researchers have emphasized greater marital instability among black women than among white women to help explain why more black women work (see, for example, Cain 1966; Sweet 1973; Johnson and Skinner 1986). Yet, with the exception of the Japanese, Asian immigrant women have relatively low divorce and separation rates. The incentive to work as insurance against future marital dissolution should be weaker for married women in most Asian immigrant groups than for European and Canadian immigrant women.

Fourth, the presence of preschool children is negatively associated with female labor force participation (Bowen and Finegan 1969; Nakamura and Nakamura 1992). Yet, Asian immigrant women are more likely to have young children at home than are nonHispanic white immigrant women. Surprisingly, the group with the lowest number of children per family, the Japanese, has the lowest labor force participation, whereas the group with the highest number of children per family, the Filipinos, has the highest labor force participation.

Finally, with the exception of the Japanese, country-of-origin female labor force participation rates would also suggest lower labor force participation among Asian immigrant women than among European and Canadian immigrant women. ${ }^{2} \mathrm{On}$ the other hand, Asian immigrant women are highly educated and relatively young, characteristics that might explain their comparatively high labor force participation.

\footnotetext{
${ }^{2}$ In the years $1960-80$, the labor force participation of women in Asian countries tended to be lower than that of European and Canadian women. The consistent exception to this pattern is Japan, in which female participation rates equaled or exceeded those of European countries and Canada (U.S. Bureau of the Census 1992).
} 
Table 1. Characteristics of 25-64-Year-Old Asian and Non-Hispanic White Immigrant Married Women, 1980. ${ }^{\mathrm{a}}$

\begin{tabular}{|c|c|c|c|c|c|c|}
\hline \multirow[b]{2}{*}{ Characteristic } & \multicolumn{6}{|c|}{ Group } \\
\hline & Japanese & Indian & Korean & Chinese & Filipino & $\begin{array}{c}\text { Non- } \\
\text { Hispanic } \\
\text { White }\end{array}$ \\
\hline Percent in Labor Force ${ }^{b}$ & 26 & 58 & 61 & 65 & 83 & 51 \\
\hline \multicolumn{7}{|l|}{ Time in U.S.: } \\
\hline Less Than 5 Years & 60 & 39 & 48 & 30 & 24 & 15 \\
\hline Less Than 10 Years & 77 & 81 & 84 & 55 & 60 & 27 \\
\hline Percent English Proficient ${ }^{c}$ & 15 & 64 & 15 & 29 & 63 & 59 \\
\hline Marital Dissolution Rate ${ }^{\mathrm{d}}$ & 9.5 & 2.8 & 7.2 & 4.2 & 6.5 & 9.6 \\
\hline $\begin{array}{l}\text { Average Number of Children } \\
\text { at Home }\end{array}$ & 1.43 & 1.68 & 1.98 & 1.77 & 2.09 & 1.08 \\
\hline Percent with Children Under 6 & 38 & 41 & 28 & 28 & 34 & 12 \\
\hline Number of Children Ever Born & 1.55 & 1.87 & 2.21 & 2.26 & 2.58 & 2.36 \\
\hline Average Education & 13.67 & 14.33 & 13.38 & 12.20 & 14.42 & 10.97 \\
\hline Average Potential Experience ${ }^{\mathrm{e}}$ & 15.51 & 13.83 & 17.54 & 20.65 & 17.90 & 26.65 \\
\hline Sample Size ${ }^{\mathrm{f}}$ & 790 & 2,249 & 1,815 & 3,719 & 3,342 & 531 \\
\hline
\end{tabular}

Source: Authors' estimates based on 1980 Census of Population, $5 \%$ "A" Public Use Sample.

${ }^{a}$ Includes only immigrant women who are married to men of the same race and nativity.

${ }^{\mathrm{b}} \mathrm{A}$ woman is considered to be in the labor force in 1980 if she reports positive earnings, positive weeks worked, and positive hours per week.

'A person was classified as proficient if she reported speaking only English or speaking English very well.

${ }^{\mathrm{d}}$ Divorce rates were derived by dividing the number of women who were divorced or separated in 1980 by the number of women in that age category who were ever married.

ePotential experience is measured by a woman's age minus her years of schooling minus 6 .

${ }^{\mathrm{f}} \mathrm{A} 1 \%$ sample of non-Hispanic whites was used. None of the other groups were subsampled.

\section{Previous Research on the Earnings and Labor Force Participation of Immigrant Women}

Whether a woman works can be viewed as the observed outcome of a decision-making process in which she compares the wage she will receive if she works (the market wage) with the wage she must receive in order to work (the reservation wage). Within this theoretical framework, researchers have identified several factors that may be particularly relevant to the work decisions of married immigrant women. These include the transferability of country-of-origin skills to the U.S. labor market, family circumstances, and cultural factors.

\section{Skill Transferability}

Recognition of the importance of skill transferability in explaining immigrant earnings and labor force behavior is most closely associated with the work of Chiswick. In various analyses of 1970 Census data, Chiswick found that immigrant men initially earn less than native-born men of equivalent education and experience, but that with time in the United States their relative earnings increase. He also found that there was less of an initial earnings gap for men who originated from English-speaking countries. (Chiswick 1978, 1979; Chiswick and Miller 1992.)

Chiswick reasoned that the level of U.S. labor market skills among immigrants underlies both the apparent growth in immigrant earnings (with time in the United States, skills relevant to the U.S. labor market are learned) and intergroup differences in immigrant earnings (groups with skills that are more readily transferable to the U.S. labor market will have higher initial earnings). Extending the same framework to immigrant 
women, Chiswick (1980) found that the hourly earnings of immigrant women tend to increase with years since migration.

In an analysis of turn-of-the-century immigrants, Blau also found that the earnings of immigrant women increased with years in the United States. In accordance with the skills assimilation model proposed by Chiswick, Blau hypothesized that the relative earnings of immigrant women increase "as they become acclimatized to their new surroundings and seek out the best opportunities to utilize their skills and abilities" $(1980: 22)$.

Theoretically, skill transferability would affect female labor force participation (the subject of this paper's analysis) through the market wage: the greater the similarity between an immigrant's country-of-origin skills and U.S. labor market skills, the higher her market wage; immigrants whose country-oforigin skills closely match those for which there is a demand in the United States would, ceteris paribus, have higher labor force participation than immigrants whose skills are less closely aligned with U.S. labor market demands.

In a further exploration of the skills transferability thesis, Chiswick compared women who migrated with their husbands with those who migrated prior to marriage. Hypothetically, women who migrated on their own would be "more likely to have skills that are readily transferable to the United States" and hence likely to have higher earnings than women who migrated because of their husbands' economic opportunities (Chiswick 1980:189-90). Yet, empirical evidence for this hypothesis is mixed, with marriage prior to migration found to be positively associated with labor force participation for some groups.

\section{Family Circumstances}

In contrast to Chiswick and Blau, Long (1980) found that the earnings of white married immigrant women decreased with years in the United States. The estimated earnings decrease prompted Long to consider an immigrant woman's labor force behavior in the context of her family. In particular, Long speculated that immigrant women work in part to support their husbands' investment in U.S.-specific skills:

Wives in immigrant families that have recently entered the United States may have to work to help finance their husbands' initial investments in schooling or job skills required in U.S. labor markets. Later, as earnings of their spouses rise with time in the United States, foreign-born wives reallocate their time from market to nonmarket activities and their earnings are reduced. (Long 1980:628)

Long did not explicitly test this hypothesis by linking a woman's labor force participation to her husband's time in the United States. To the extent that husbands' investment decisions influence wives' labor force participation, we would expect the husband's years since migration to be inversely associated with the wife's labor force participation.

In a more recent analysis, MacPherson and Stewart (1989) found that whether a husband was in school was only weakly related to the wife's propensity to work. Yet, there are many kinds of potential investment behavior by immigrants, such as learning English, on-the-job training, working in family-owned businesses, getting clued in to job information networks, and changing jobs. Since the steps that pave the path of assimilation are both numerous and varied, a more general approach may be warranted in testing whether immigrant women work in part to help support their husbands' investments in U.S.-specific skills.

Another potentially important family circumstance is whether a family shares its home with relatives who may assist in the care of children, thus freeing a woman to work. ${ }^{3}$ Although the empirical evidence on the importance of live-in relatives for black/white differences in female labor force participation is ambiguous, ${ }^{4}$ two analyses of immigrant

\footnotetext{
${ }^{3}$ In her analysis of labor force participation, Goldin (1977:107) writes: "The higher incidence of the extended family structure...might also be responsible for the smaller response of black women to the presence of young children." See Presser (1992) for additional references and a more general study of child care arrangements and women's labor force participation.

${ }^{4}$ Refer to Cain (1966, pp. 81-82 and Appendix G) and Hall $(1973: 145,148)$.
} 
women have found a positive association between relatives in the home and the propensity of immigrant women to work (Duleep 1988; MacPherson and Stewart 1989).

\section{Cultural Factors}

Using the 1976 Survey of Income and Education, Reimers (1985) found that the labor force participation of immigrant women increased with time in the United States. Reimers attributed this growth to cultural assimilation, in contrast to Chiswick's skills assimilation thesis:

Cultural differences may give rise to systematic differences in utility functions that lead to systematic differences in behavior by women ... . who face the same constraints or opportunity set. Such cultural differences in utility functions no doubt are historically shaped by economic as well as other circumstances, and they evolve, but more slowly than the economic conditions. Ethnic differences in attitudes are, therefore, presumably more pronounced in the first generation of immigrants than in their American-born descendants. (Reimers 1985:251)

According to the cultural hypothesis, intergroup variations in female labor force participation may persist even after controlling for all measurable differences among individuals in levels of current characteristics and conditions. Clues for the causes of these residual differences may only be discovered by examining the history of individual groups. ${ }^{5}$

\section{Summary of Research and Analytical Strategy}

The research we have reviewed introduces three broad questions concerning variations in the labor force participation of women across immigrant groups. (1) Do differences in U.S.-specific skills among immigrant women explain differences in their labor force participation? (2) To what extent are

\footnotetext{
${ }^{5}$ For example, Goldin attributes the higher labor force participation of black versus white women, controlling for economic and demographic differences, to the lingering effect of slavery on women's attitudes toward market work (Goldin 1977). See Lehrer (1992) for an exploration of more recent black-white differences in women's labor force participation.
}

variations in labor force participation across groups explained by variations in family circumstances such as the husband's level of U.S.-specific skills and whether the family lives with other relatives? (3) Controlling for differences across groups in the levels of U.S.-specific skills and family circumstances, are there persistent cultural differences that affect the labor force participation of immigrant women?

In the following sections we seek to identify the determinants of differences in labor force participation between married immigrant women from Asian countries and married immigrant women from Europe and Canada. We employ the methodology that Goldin and others have used to explore differences in labor force participation between black and white women. A pooled probit model is estimated that includes a dichotomous variable for each country of origin. From an analytical point of view, explaining differences across groups means identifying a set of variables that, when held constant, eliminates group-specific effects. Remaining group-specific effects would occur if there are omitted relevant variables that are at different levels across groups, or there are genuine differences among groups in their response to a set of explanatory variables.

\section{Basic Pooled Model}

We begin our analysis by examining how participation rates are affected once variables conventionally included in female labor force participation models and U.S.specific skills are held constant across groups. Years since migration and English proficiency are used to measure U.S.-specific skills. Details of the model specification are given in the Appendix.

The first column of Table 2 shows the difference between each Asian immigrant group's unadjusted sample probability of working and the corresponding probability for our benchmark group of non-Hispanic white women. The second column shows the probit coefficients on the Asian group variables from the multivariate model. A positive coefficient implies that women in a specific group are more likely to work than non- 
Table 2. The Effect of Asian Origin on the Labor Force Participation of Immigrant Women. (Benchmark Group Is Non-Hispanic White Immigrant Women)

(Asymptotic T-Statistics in Parentheses)

\begin{tabular}{lcccc}
\hline Nationality & Unadjusted Change in Probability $^{\mathrm{a}}$ & \multicolumn{2}{c}{ Probit Coefficient $^{\mathrm{b}}$} & Adjusted Change in Probability $^{\text {C }}$ \\
\hline Japanese & -.25 & -.504 & $(5.39)$ & -.18 \\
Indian & .07 & .183 & $(3.26)$ & .07 \\
Korean & .10 & .349 & $(5.62)$ & .14 \\
Chinese & .14 & .349 & $(7.63)$ & .14 \\
Filipino & .32 & .914 &.$(15.59)$ & .34 \\
\hline
\end{tabular}

\footnotetext{
${ }^{\text {a }}$ These numbers are the sample probability of working for each Asian group minus the corresponding probability for non-Hispanic white immigrant women.

${ }^{b}$ The equation log-likelihood for the pooled probit model is -7458.347 ; the log-likelihood R-square is .162. The sample size is 12,446 .
}

Hispanic white immigrant women, holding other variables constant. To better gauge the magnitude of the Asian effects on labor force participation, the third column shows the difference in the estimated probability of working between the benchmark group and each Asian group, evaluated at the pooled sample means for all other explanatory variables.

Surprisingly, the adjusted change in the probability of working with ethnic group status (column 3) is quite similar to the unadjusted change (column 1): the effect of Japanese origin is only slightly smaller than, and the other Asian origin effects are as large as or larger than, the unadjusted effects.

To further explore the effects of the explanatory variables, we separately estimated the model for each group. ${ }^{6}$ Of particular note are group-specific responses to education, experience, English proficiency, and years since migration. At all levels of education the effect of an additional year of schooling on labor force participation is smaller for Asian than for non-Hispanic white immigrant women. Similarly, the effect of potential experience is smaller for Asians. Controlling for years since migration, the coefficient on experience measures the effect of country-oforigin experience on the decision to work. To the extent that years of schooling and experience affect labor force participation through the market wage, the smaller effect

\footnotetext{
${ }^{6}$ Group-specific regressions are available in Duleep, Regets, and Sanders (1993).
}

of these variables may reflect lower transferability of country-of-origin schooling and experience to the U.S. labor market for Asian immigrant women than for non-Hispanic white immigrant women. The group-specific regressions also reveal that for all groups labor force participation increases with English language proficiency and that there is a tendency for labor force participation to initially increase with years since migration (consistent with the skills and cultural assimilation theories) and then to decrease (consistent with Long's investment hypothesis).

In summary, group-specific regressions reveal that the number of years an immigrant woman has been in the United States and her English language proficiency, as well as characteristics traditionally included in female labor force participation models, such as the number and ages of children, are important determinants of the decision to work. Nevertheless, holding these variables constant across groups in the pooled regression has very little effect on large intergroup differences in labor force participation. In the sections that follow, various explanations for these persistent group-specific effects are explored.

\section{The Role of Relatives in the Home}

Variations in the presence of relatives in the home may help explain intergroup variations in female labor force participation. By providing day-care services, adult relatives may lower the cost to married women of working. 
To test for a "day-care" effect, we included in the model whether adult relatives were present in homes with children under 12 years of age. Because live-in relatives may be a financial burden and, via an income effect, increase the likelihood of a woman working, we also included per-capita non-wife family income (including the earnings of other relatives).

As shown in Table 3, the presence of adult relatives in the home has a large positive effect on the labor force participation of married women with young children. ${ }^{7}$ Livein relatives do not apparently increase an immigrant woman's labor force participation by placing a greater burden on family income, since the estimated coefficient on the per-capita income variable is small and positive. Although the presence of relatives is positively associated with the likelihood of immigrant women working, controlling for this variable has very little effect on the magnitude of the Asian group coefficients: the coefficients on Asian origin differ only slightly from the corresponding coefficients shown in Table 2.

\section{Work Experience in Country of Origin}

Given the strong association between past and present work behavior (Heckman 1981; Nakamura and Nakamura 1985), the labor force participation of immigrant women may simply reflect work patterns established in the country of origin. To test this hypothesis, we used census information on whether respondents worked five years prior to the census. When we limit our sample to women who migrated to the United States in the period 1975-80, this information conveys whether a woman worked in her country of origin.

Our model, including the previously discussed variables concerning live-in relatives, was estimated on the subsample of women who migrated between 1975 and 1980 (lefthand side of Table 4). We then added whether

\footnotetext{
${ }^{7}$ An analysis that interacts the presence of live-in relatives with each Asian group reveals a positive effect on wives' labor force participation for all groups. Model estimations interacting key explanatory variables with country of origin are available from the authors.
}

Table 3. Selected Coefficients from

Pooled Probit Model Adjusting for Presence of Adult Relatives in the Home: 25-64-Year-Old Immigrant Married Women, 1980.

\begin{tabular}{lcc}
\hline $\begin{array}{l}\text { Independent } \\
\text { Variable }\end{array}$ & Coefficient & $\begin{array}{r}\text { Asymptotic } \\
\text { T-Statistic }\end{array}$ \\
\hline $\begin{array}{l}\text { Adult Relatives in Homes } \\
\text { with Young Children }\end{array}$ & .403 & $(6.67)^{*}$ \\
Per-Capita Non-Wife & & \\
Family Income & .00005 & $(8.84)^{*}$ \\
Japanese & -.471 & $(5.00)^{*}$ \\
Indian & .190 & $(3.38)^{*}$ \\
Korean & .364 & $(5.81)^{*}$ \\
Chinese & .347 & $(7.53)^{*}$ \\
Filipino & .887 & $(14.93)^{*}$ \\
Equation Log-Likelihood & \multicolumn{2}{c}{-7396.609} \\
Log-Likelihood R-Square & \multicolumn{2}{c}{.171} \\
Sample Size & \multicolumn{2}{c}{12,446} \\
\hline
\end{tabular}
test).

*Statistically significant at the .05 level (two-tailed

a woman had worked full-time in 1975 , thus adjusting for probable work behavior in country of origin (right-hand side of Table 4). Consistent with analyses of native-born women, the effect of previous work is large and positive. ${ }^{8}$ Evaluated at sample means, this coefficient indicates that having worked full-time prior to migration is associated with a 28 percentage point increase in the probability of working in the United States. The modest size of the change in the Asian origin coefficients with the addition of this variable, however, suggests that country-of-origin labor force participation does not explain intergroup variations in U.S. labor force participation.

To further probe the role of previous work experience, we measured the effect of working full time in 1975 on our full sample. This estimation indicates that previous work increases the probability of working in 1980 by 49 percentage points. A comparison of the coefficient from this estimation with the coefficient on past work behavior in the subsample of women who immigrated after 1975 suggests that the effect of country-of-

\footnotetext{
${ }^{8}$ For a more detailed analysis of the effect of previous work behavior on the labor supply of immigrant women, refer to Duleep and Sanders (1991).
} 
Table 4. Effect of Having Worked Full-Time in Country of Origin on Labor Force Participation in America: Married Women Who Immigrated in 1975 or After.

(Selected Probit Coefficients)

(Asymptotic T-Statistics in Parentheses)

\begin{tabular}{lcc}
\hline Nativity & $\begin{array}{c}\text { Not Including } \\
\text { Previous Work Experience }\end{array}$ & $\begin{array}{c}\text { Including } \\
\text { Previous Work Experience }\end{array}$ \\
\hline Whether Worked Full-Time in 1975 & & $.720(14.60)^{*}$ \\
Japanese & $-.707(6.11)^{*}$ & $-.619(5.21)$ \\
Indian & $.555(7.51)^{*}$ & $.640(8.43)^{*}$ \\
Korean & $.806(10.37)^{*}$ & $.813(10.24)^{*}$ \\
Chinese & $.567(8.05)^{*}$ & $.504(6.99)^{*}$ \\
Filipino & $1.350(14.38)^{*}$ & $1.271(13.16)^{*}$ \\
Equation Log-Likelihood & -2380.04 & -2270.62 \\
Log-Likelihood R-Square & .236 & .271 \\
Sample Size & 4,225 & 4,225 \\
\hline
\end{tabular}

*Statistically significant at the .05 level (two-tailed test).

origin work experience on current labor force participation is smaller than the effect of U.S. work experience. One interpretation of this finding is that the market wage return to immigrants' country of origin work experience is less than the return to U.S. work experience.

\section{Migrating Before or After Marriage}

Theoretically, one would expect women who migrate on their own to be more likely to have skills that are transferable to the American labor market and hence have higher wages than women who migrate because of their husbands' economic opportunities. We would therefore expect lower labor force participation among women who married before migration. If, after controlling for other variables, women in Asian groups other than the Japanese are less likely to marry prior to migration, and if the effect of marrying prior to migration is similar in the anticipated direction across groups, then controlling for this variable might explain some of the across-group variation in labor force participation.

The first column of Table 5 shows selected coefficients from a model including a variable for whether a woman married prior to migration. ${ }^{9}$ The coefficient on this variable is

\footnotetext{
${ }^{9}$ This model was estimated on the complete sample. Marriage prior to migration was approximated by
}

small and not statistically significant; comparing the Asian origin coefficients with the corresponding coefficients shown in Table 3, we see that its inclusion has almost no effect on the estimated effects of Asian origin. To find out whether the effect of this variable was similar across groups, we re-estimated the model interacting each country of origin with marriage prior to migration. We found that marriage prior to migration was associated with lower labor force participation among Japanese, Chinese, and Filipino women, but had no effect or a positive effect among Korean, Indian, and non-Hispanic white women.

\section{The Decision to Work as a Family Investment Strategy}

The first row of Table 6 shows the approximate proportionate difference between the earnings of men who immigrated during 1975-80 and the earnings of "otherwise similar" immigrants in the same group who have resided in the United States 30 years or more. Ignoring unmeasured differences among intertemporal cohorts, these coefficients portray the amount by which the earnings of immigrant men in each group are likely to grow with time in the United States: the

comparing years since marriage (computed as age age at marriage) with the midpoint of the individual's years since migration category. 
Table 5. Effects on Labor Force Participation of Selected Characteristics: Pooled Probit Model Estimated for All Married Immigrant Women and "Permanent" Immigrants.

(Asymptotic T-Statistics in Parentheses)

\begin{tabular}{|c|c|c|}
\hline Category & All Immigrants & Permanent Immigrants \\
\hline \multicolumn{3}{|l|}{ Immigrant Groups } \\
\hline Japanese & $.470(4.98) *$ & $-.089(0.35)$ \\
\hline Indian & $.190(3.38)^{*}$ & $.070 \quad(0.62)$ \\
\hline Korean & $.367(5.85) *$ & $-.016(0.13)$ \\
\hline Chinese & $.351(7.58) *$ & $.318(4.20)^{*}$ \\
\hline Filipino & $.890(14.95)^{*}$ & $.671(7.13)^{*}$ \\
\hline \multicolumn{3}{|l|}{ Wife's Years Since Migration } \\
\hline $0-5$ & $-.578(7.67) *$ & $-.631(4.07) *$ \\
\hline $6-10$ & $-.077(1.12)$ & $-.571(4.83) *$ \\
\hline $11-15$ & $-.059(0.95)$ & $-.425(4.14)^{*}$ \\
\hline $16-20$ & $-.110(1.76)$ & $-.298(2.98)^{*}$ \\
\hline $21-30$ & $-.401(7.79) *$ & $-.432(5.88)^{*}$ \\
\hline \multicolumn{3}{|l|}{ Husband's Years Since Migration } \\
\hline $6-10$ & & $.931(9.73) *$ \\
\hline $11-15$ & & $.706(8.29)^{*}$ \\
\hline $16-20$ & & $.458(5.66) *$ \\
\hline $21-30$ & & $.152(2.40)^{*}$ \\
\hline Adult Relatives in Homes with Young Children & $.401(6.63) *$ & $.448(4.83)^{*}$ \\
\hline Whether Married Prior to Migration & $.035 \quad(0.93)$ & $-.200(3.55)^{*}$ \\
\hline Equation Log-Likelihood & -7396.179 & -3238.661 \\
\hline Log-Likelihood R-Square & .171 & .210 \\
\hline Number of Observations & 12,446 & 5,660 \\
\hline
\end{tabular}

\footnotetext{
ammigrant women married to U.S. citizens.

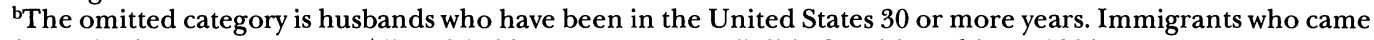
to the United States between 1975 and 1980 were not as yet eligible for citizenship in 1980 .

* * Statistically significant at the .05 level (two-tailed test).
}

larger the negative coefficients on years since migration, the larger the likely earnings growth. ${ }^{10}$ Viewed from a human capital perspective, the growth in earnings with time in the United States, holding schooling and years of experience constant, likely reflects investment in human capital specific to the U.S. labor market, such as the development of job contacts, job training, and English language proficiency. Accordingly, the gap between the current earnings of recent immigrants and their "potential earnings" (with

\footnotetext{
${ }^{10}$ Earnings mobility is inferred from earnings differences across immigrant cohorts. An implicit assumption is that the earnings of the most recent entrants will, with time in the United States, equal the earnings of longer-term immigrants with similar characteristics. These estimates may also, however, reflect inter-cohort differences in unmeasured characteristics (Borjas 1985) and emigration. For information on the extent and distribution of emigration, refer to Jasso and Rosenzweig (1990, Chap. 3).
}

time in the United States) provides a measure of the average extent to which members of particular groups invest in U.S.-specific skills.

For all groups, there is a tendency for this gap to decrease the longer immigrants are in the United States. The gap for recent immigrant men between current earnings and "expected" earnings with time in the United States is generally larger for men from Asian countries than it is for men from Europe and Canada. With time in the United States, however, the earnings of Asian immigrant men grow rapidly and approach the earnings of non-Hispanic white immigrant men with comparable levels of skills and characteristics (Duleep 1988). ${ }^{11}$ These patterns suggest that

${ }^{11}$ Using 1970 and 1980 census data, Duleep (1988, Chap. 8) and Lalonde and Topel (1991) found the earnings growth of actual cohorts of immigrant men and cross-sectional estimates to be similar. Work by 
Table 6. Percentage Impact of Years Since Migration on Annual Earnings of 25-64-Year-Old Immigrant Men, by Group, 1980.

\begin{tabular}{|c|c|c|c|c|c|c|c|}
\hline Years Since Migration & Filipino & Chinese & Korean & Indian & Japanese & $\begin{array}{c}\text { Non- } \\
\text { Hispanic } \\
\text { White }\end{array}$ & $\begin{array}{c}\text { Japanese: } \\
\text { U.S. } \\
\text { Citizens } \\
\text { Only }\end{array}$ \\
\hline $0-5$ & $-.74^{*}$ & $-.69 *$ & $-.76^{*}$ & $-.55^{*}$ & -.09 & $-.27 *$ & $-.54 *$ \\
\hline $6-10$ & $-.38^{*}$ & $-.36^{*}$ & -.37 & -.19 & -.17 & -.10 & $-.34^{*}$ \\
\hline $11-15$ & $-.24^{*}$ & $-.25^{*}$ & -.22 & -.02 & -.07 & -.04 & .10 \\
\hline $16-20$ & $-.14^{*}$ & $-.14^{*}$ & -.12 & .04 & -.07 & -.07 & -.11 \\
\hline $21-30$ & -.11 & $-.12 *$ & -.19 & .04 & -.12 & .06 & -.13 \\
\hline
\end{tabular}

Notes: The results indicate the approximate proportionate amount by which the earnings of immigrant men, who immigrated during a specified time period, differ from the earnings of immigrants in the same group who have resided in the U.S. 30 years or more. The coefficients are derived from group-specific regression estimations in which the dependent variable is the natural logarithm of earnings and the explanatory variables include education, work experience, region, location, marital status, and disability.

*Statistically significant at the .05 level.

the extent to which immigrants invest in U.S.specific skills generally declines over time and that upon entry to the United States, Asian immigrant men are more likely to invest in skills specific to the U.S. labor market than are non-Hispanic white immigrant men.

The Japanese are an exception to this pattern. Unlike the other Asian groups, recent Japanese immigrant men do not earn significantly less than comparable long-term Japanese immigrants. The likely explanation for this anomaly is that many recent Japanese immigrant men work in Japanese firms located in the United States or in firms with Japanese interests that utilize their country-of-origin training and background. These immigrants suffer no earnings loss because the skills they acquired in Japan are immediately relevant to their American-based jobs. Nor would they undertake investments that would result in higher earnings only with permanent American residence, since their intention is to return to Japan.

To test this conjecture, we estimated the effect of years since migration on the small

Duleep and Regets (1992a, 1992b) suggests that the reason for the similarity is that as starting earnings have decreased (increased), earnings growth has increased (decreased). Longitudinal analysis by Jasso and Rosenzweig (1990, Chap. 7) of a 1971 cohort of legal immigrants suggests that cross-sectional and cohort estimates may underestimate returns to U.S. experience due to selective out migration, and that returns to U.S. residence are greatest when U.S. experience is less than 6.3 years and thereafter decrease. subset of Japanese immigrant men who had become American citizens by the year 1980 . (Excluding immigrants who have retained their Japanese citizenship eliminates from the analysis people who intend to return to Japan.) Among Japanese immigrant men who clearly intend to stay permanently in the United States, recent immigrants, like other Asian immigrant men, earn substantially less than immigrants of longer U.S. residence (Table 6, last column).

Consideration of our earlier estimates of the propensity of married immigrant women to work, in conjunction with the estimated effects of years since migration on the earnings of all immigrant men, including citizens and non-citizens, shown in the first six columns of Table 6 , reveals that the groups with the largest expected growth in immigrant men's earnings (Filipinos, Koreans, and Chinese, followed by Indians) are those with the highest labor force participation of married women, and the groups with the smallest expected growth in men's earnings (nonHispanic whites and Japanese) are those with the lowest female participation rates. This pattern suggests that financing their husbands' investments in skills that will help them pursue a career in America is a factor underlying immigrant women's decision to work. ${ }^{12}$

${ }^{12}$ The family investment hypothesis parallels research on migration decisions in a family context (see Mincer 1978; Polachek and Horvath 1977; DaVanzo 1976; Sandell 1975, 1977). 
To test this hypothesis, we adjusted our female labor force participation model for variables that are likely correlated with a husband's propensity to invest in skills specific to the U.S. labor market. A promising candidate in this regard is an intention to stay permanently in the United States. Investments such as starting a business, taking jobs with on-the-job training, and learning English take time and money and generally result in lower earnings at first. These investments would not be made if there were not a prospect of reaping benefits from them. Thus, immigrants who intend to stay permanently in the United States would be more likely to invest in skills specific to the U.S. labor market than immigrants who do not plan on making the United States their permanent home. ${ }^{13}$ The latter are likely to be persons who can work here without investing, either because their jobs do not require U.S.-specific skills (as we had hypothesized for the majority of recent Japanese immigrant men) or because their country-of-origin skills are highly transferable to the U.S. labor market. ${ }^{14}$

Given that a family intends to stay in the United States, we would expect that the more recent the husband's year of immigration, the greater his likely investment in U.S.-specific skills and the greater the propensity of the wife to work, holding constant her own year of immigration. We would therefore expect the husband's and wife's years since migration to have countervailing effects on the wife's labor force participation: with time in the United States, the wife gains U.S.specific skills, increasing her market wage and thereby her propensity to work; simultaneously, the husband's U.S.-specific skills increase, decreasing his propensity to invest in U.S.-specific skills, and thereby decreasing the wife's propensity to work. This consideration suggests that the positive effect of a

\footnotetext{
${ }^{13}$ The connection between permanence and investment in U.S.-specific skills has been explored in a variety of contexts (for example, Erikson 1972; Piore 1979; Borjas 1982; Duleep 1988).

${ }^{14}$ Families that initially plan on returning to their home country may end up making the United States their permanent home. Nevertheless, one would expect initial intentions to have important effects on investment behavior.
}

wife's years since migration on her labor force participation may be underestimated in studies that do not also control for the husband's years since migration.

Alternatively, to the extent that women in immigrant families that anticipate living permanently in the United States are more likely to work than are those in families that intend to leave, the estimated growth in labor force participation with time in the United States may be the spurious result of a selective emigration of women who are less likely to be labor force participants: as the non-permanent immigrants return to their country of origin, the labor force participation of immigrant women appears to increase. Selective emigration could also explain the positive effect on the wife's labor force participation of live-in relatives if families that do not intend to stay in the United States are less likely to have relatives living with them, and women in non-permanent families are less likely to work. Restricting the analysis to "permanent" immigrant families would test the causal importance of both the wife's years since migration and the presence of relatives in the home.

To determine whether intergroup differences in female labor force participation persist when only immigrants who clearly intend to stay in the United States are considered, we estimated our model on a subset of women whose husbands were citizens in 1980. To test whether the recency of the husband's immigration (as distinguished from the wife's) affects the likelihood of the wife working, we included in the model the husband's year of immigration.

Returning to Table 5, we see the estimated coefficients on Asian descent, the presence of other relatives, and the wife's years since migration from the last pooled regression in the first column alongside the estimated coefficients from a regression on the subset of "permanent immigrants," which also includes the husband's years since migration as an explanatory variable. ${ }^{15} \mathrm{~A}$ comparison of the

\footnotetext{
${ }^{15}$ The estimated model includes all variables in the basic regression (Appendix) as well as live-in relatives, per capita non-wife family income, and whether migrated before marriage.
} 
two columns is notable for what changes as well as for what does not change.

Limiting the analysis to women in permanent immigrant families lowers the effect on the probability of working of Filipino descent and practically eliminates the effects of Indian, Korean, and Japanese descent. According to the coefficients on the husband's year of immigration, the probability of a married woman working decreases as her husband's years since migration increase ${ }^{16}$ The positive effect of the wife's years since migration persists and indeed increases. This result suggests that the effect of wives' years since migration has been underestimated in previous analyses and is not due to a selective emigration. The positive effect of live-in relatives on the wife's labor force participation also persists.

\section{Conclusions}

Our investigation of the determinants of labor force participation among married Asian immigrant women in 1979 has confirmed and strengthened some findings of previous studies, but also raised new questions. Consistent with other studies, ours finds that the probability of immigrant women's participation in the labor force in 1979 was positively associated with proficiency in English, years since immigration, and the presence in the home of other relatives. We also find, consistent with the skills transferability theory, that labor force participation was less closely correlated with work experience gained in the country of origin than with work experience gained in the United States.

Notwithstanding the statistically significant effects of these factors across individuals, however, we find that when we control for them, strong group-specific differences in labor force participation persist. In particular, these variables do not explain why mar-

\footnotetext{
${ }^{16}$ We also estimated the model shown in the second column of Table 5 for each group, sample sizes permitting. (The sample size of Japanese women married to Japanese-origin U.S. citizens was too small to allow its separate estimation.) For all groups, husband's years since migration is inversely associated with wife's labor force participation, controlling for her own years since migration.
}

ried Asian immigrant women, with the exception of the Japanese, are more likely to work than are their counterparts from $\mathrm{Eu}-$ rope and Canada. To approach an explanation of that pattern, we have found that it is necessary to broaden the focus to include a consideration of the husbands' level of economic assimilation.

With the exception of the Japanese, immigrant men from Asian countries initially earn substantially less than European and Canadian immigrant men with similar levels of education and years of work experience. A promising explanation for the lower initial earnings of men in most Asian groups is that their skills upon arrival in the United States are less transferable to the American labor market. Thus, their initial years in the United States are characterized by greater investment in U.S.-specific skills.

Our estimates appear to be consistent with a family investment strategy: evidence from both across groups and within groups suggests that whether a husband invests in human capital specific to the U.S. labor market, and also the extent of that investment, are factors affecting a woman's decision to work. We find that the groups with the largest expected growth in immigrant men's earnings are the groups with the highest labor force participation of married immigrant women. Although unexplained differences persist, differences across groups in the permanence of immigrant husbands and their degree of assimilation help explain some intergroup differences in the labor force participation of married women. Finally, the labor force participation of immigrant wives is inversely associated with their husbands' years since migration, holding their own years since migration constant.

Evaluations of immigration policy have tended to focus on the earnings of immigrant men. One conclusion from that work is that immigrants lacking U.S.-specific skills have lower initial earnings. The work presented here is subject to the biases of cross-sectional analysis and requires further exploration with longitudinal data as well as extension to other detailed country-of-origin groups. There are also persistent differences among the groups we have considered that we are unable to 
explain. Understanding these differences may require a more historical and institutional analysis (see, for example, Goldfarb et al. 1984). Nevertheless, our analysis suggests that there is a family response to immigration that may help offset the low earnings of immigrant men initially lacking skills specific to the American labor market.

\section{APPENDIX}

\section{Specification of the Basic Model ${ }^{17}$}

The dependent variable is whether a woman worked at least one week in 1979. The explanatory variables in our basic reduced form model can be divided into those affecting a woman's reservation wage and those affecting her market wage.

A woman's reservation wage is affected by the monetary and psychic costs of her working outside the home and by the availability and certainty of other sources of income. Variables that we used to capture the cost of a woman working outside the home include several child status variables (the number of children at home, whether the family's youngest child is less than $1,1-5,6-11$, and 12-17 years old, and whether children 12 years of age and older are present in homes with children under 12 years of age) and whether the husband is self-employed. Variables measuring the availability and certainty of other sources of income include the husband's earnings, whether he had ever been

${ }^{17}$ For a description and documentation of the $5 \%$ "A" sample of the 1980 Census, refer to U.S. Bureau of the Census (1983). Copies of the data and computer programs used to generate our results are available on unemployed in 1979, and the family's level of assets, as measured by the sum of their dividends, rents, and interest.

A woman's market wage is affected by her skills and by employment opportunities in the area in which she lives. Skill levels are measured by years of schooling (a 2-part spline breaking at 16 years of schooling), English language proficiency (speaks only English, speaks English very well, speaks English not well, speaks English not at all), whether disabled, year of immigration (1975$80,1970-74,1965-69,1960-64,1950-59)$, age - schooling -6 (to measure potential years of work experience), experience squared, education - experience, and to help measure likely years of work experience, age at first marriage and number of children ever born. To adjust for demand conditions, six regions (including California and Hawaii) and urban/rural location (five census categories) are included.

request. Address inquiries to Harriet Orcutt Duleep, 4417 Yuma St. N.W., Washington, D.C. 20016, or Seth Sanders, Heinz School of Public Policy and Management, Carnegie-Mellon University, Pittsburgh, PA 15213.

\section{REFERENCES}

Blau, Francine. 1980. "Immigration and Labor Earnings in Early Twentieth Century America." In Julian Simon and Julie DaVanzo, eds., Research in Population Economics, Vol. 2. Greenwich, Conn.: JAI Press, pp. $21-41$.

Borjas, George. 1987. "Self Selection and Immigrants." American Economic Review, Vol. 77 (September), pp. 531-53.

. 1985. "Assimilation, Changes in Cohort Quality, and the Earnings of Immigrants." Journal of Labor Economics, Vol. 3 (October), pp. 389-463.

1982. "The Earnings of Male Hispanic Immigrants in the United States." Industrial and Labor Relations Review, Vol. 3 (April), pp. 343-53.

Bowen, William, and T. Aldrich Finegan. 1969. The Economics of Labor Force Participation. Princeton: Princeton University Press.

Cain, Glen. 1966. Married Women in the Labor Force: An Economic Analysis. Chicago: University of Chicago Press.
Chiswick, Barry. 1978. "The Effect of Americanization on the Earnings of Foreign-Born Men.” Journal of Political Economy (October), pp. 897-922.

. 1979. "The Economic Progress of Immigrants Some Apparently Universal Patterns." In William Fellner, ed., Contemporary Economic Problems. Washington, D.C.: American Enterprise Institute, pp. 359-99. . 1980. An Analysis of the Economic Progress and Impact of Immigrants. N.T.I.S. No. PB80-200454. Washington, D.C.: National Technical Information Service.

Chiswick, Barry, and Paul Miller. 1992. "Language in the Labor Market: The Immigrant Experience in Canada and the U.S." In Barry Chiswick, ed., Immigration, Language and Ethnicity: Canada and the United States. Washington, D.C.: American Enterprise Institute, pp. 229-96.

DaVanzo, Julie. 1976. Why Families Move: A Model of the Geographic Mobility of Married Couples. Report R-1972- 
DOL. Santa Monica, Calif.: Rand.

Duleep, Harriet Orcutt. 1986. The Economic Status of Americans of Asian Descent. U.S. Commission on Civil Rights. Washington, D.C.: GPO.

Duleep, Harriet Orcutt, and Mark C. Regets. 1992a. "Some Evidence on the Effect of Admission Criteria on Immigrant Assimilation." In Barry Chiswick, ed., Immigration, Language and Ethnic Issues: Canada and the United States. Washington, D.C.: American Enterprise Institute, pp. 410-39.

1992b. "The Elusive Concept of Immigrant Quality." Paper presented at the 1992 Annual Meeting of the American Economic Association.

Duleep, Harriet Orcutt, Mark C. Regets, and Seth Sanders. 1993. Family Ties and Economic Assimilation: A Study of Asian Immigrants. Kalamazoo, Mich.: Upjohn Institute of Employment Research, forthcoming.

Duleep, Harriet Orcutt, and Seth Sanders. 1991. "Empirical Regularities Across Cultures: The Effect of Children on Women's Work." Paper presented at the Donner Foundation-Minnesota Industrial Relations Center Conference on the Economic Well-Being of Women and Children.

Erikson, Charlotte. 1972. Invisible Immigrants: The Adaptation of English and Scottish Immigrants in 19th Century America. Miami: University of Miami Press.

Goldfarb, Robert. 1982. "Occupational Preferences in the U.S. Immigration Law: An Economic Analysis." In Barry Chiswick, ed., The Gateway: U.S. Immigration Issues and Policies. Washington, D.C.: American Enterprise Institute, pp. 412-48.

Goldfarb, Robert, Oli Havrylyshyn, and Stephen Mangum. 1984. "Can Remittances Compensate for Manpower Outflows?" Journal of Development Economics, Vol. 15, pp. 1-17.

Goldin, Claudia. 1977. "Female Labor Force Participation: The Origin of Black and White Differences, 1870 and 1880." Journal of Economic History (March), pp. 87-108.

Hall, Robert. 1973. "Wages, Income, and Hours of Work in the U.S. Labor Force." In Glen Cain and Harold Watts, eds., Income Maintenance and Labor Supply. Chicago: Rand McNally, pp. 102-62.

Heckman, James. 1981. "Heterogeneity and State Dependence." In Sherwin Rosen, ed., Studies in Labor Markets. Chicago: University of Chicago Press, pp. 91139.

Jasso, Guillermina, and Mark Rosenzweig. 1990. The New Chosen People: Immigrants in the United States. New York: Russell Sage Foundation.

Johnson, William, and Jonathan Skinner. 1986. "Labor Supply and Marital Separation." American Economic Review (June), pp. 455-69.

Lalonde, Robert, and Robert Topel. 1991. "Immigrants in the American Labor Market: Quality, Assimilation, and Distributional Effects." American Economic Review,
Papers and Proceedings (May), pp. 297-302.

Lehrer, Evelyn L. 1992. "The Impact of Children on Married Women's Labor Supply: Black-White Differentials Revisited." Journal of Human Resources (Summer), pp. 422-44.

Long, John. 1980. "The Effect of Americanization on Earnings: Some Evidence for Women." Journal of Political Economy, Vol. 88, No. 3, pp. 620-29.

MacPherson, David, and James Stewart. 1989. "The Labor Force Participation and Earnings Profiles of Married Female Immigrants." Quarterly Review of Economics and Business, Vol. 29 (Autumn), pp. 57-72.

Mincer, Jacob. 1978. "Family Migration Decisions." Journal of Political Economy (October), pp. 749-73.

Nakamura, Alice, and Masao Nakamura. 1985. The Second Paycheck: A Socioeconomic Analysis of Earnings. Orlando, Fla.: Academic Press.

. 1992. "The Econometrics of Female Labor Supply and Children." Econometric Reviews, Vol. 11, No. 1, pp. 1-71.

Piore, Michael. 1979. Birds of Passage: Migrant Labor and Industrial Societies. Cambridge: Cambridge University Press.

Polachek, Solomon, and Francis Horvath. 1977. "A Life Cycle Approach to Migration: Analysis of the Perspicacious Peregrinator." In Ronald Ehrenberg, ed., Research in Labor Economics. Greenwich, Conn.: JAI Press, pp. 103-49.

Presser, Harriet B. 1989. "Can We Make Time for Children? The Economy, Work Schedules, and Child Care." Demography (November), pp. 523-43.

Reimers, Cordelia. 1984. "Sources of the Family Income Differentials Among Hispanics, Blacks, and White Non-Hispanics." American Journal of Sociology, Vol. 89, No. 4, pp. 889-903.

1985. "Cultural Differences in Labor Force Participation Among Married Women." American Economic Review, Papers and Proceedings (May), pp. 251-55.

Sandell, Steven. 1975. "The Economics of Family Migration." In Herbert Parnes et al., eds., Dual Careers: A Longitudinal Analysis of the Labor Market Experience of Women, Vol. 4. The Ohio State University, Center for Human Resource Research. Chap. 6, pp. 141-60.

1977. "Women and the Economics of Family Migration." Review of Economics and Statistics, Vol. 59 (November), pp. 406-14.

Sweet, James. 1973. Women in the Labor Force. New York: Seminar Press.

U.S. Bureau of the Census. 1983. Census of Population and Housing, 1980: Public Use Microdata Samples, TechnicalDocumentation. Washington, D.C.: Bureau of the Census.

1992. International Statistical Database. Washington, D.C.: Bureau of the Census, Center for International Research. 